\title{
Epidemiological surveillance of West Nile neuroinvasive diseases in Italy, 2008 to 2011
}

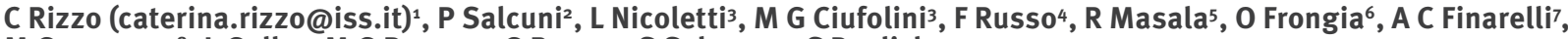

M Gramegna ${ }^{8}$, L Gallo', M G Pompa ${ }^{2}$, G Rezza ${ }^{3}$, S Salmaso ${ }^{1}$, S Declich ${ }^{1}$

1. National Centre for Epidemiology, Surveillance and Health Promotion, National Institute of Health (Istituto Superiore di Sanità, ISS), Rome, Italy

2. Ministry of Health, Department of Prevention and Communication, Rome, Italy

3. Department of Infectious, Parasitic and Immune-mediated Diseases, National Institute of Health (Istituto Superiore di Sanità, ISS), Rome, Italy

4. Regional Health Authority of Veneto, Italy

5. Regional Health Authority of Sardinia, Italy

6. Local Health Authority of Oristano, Sardinia, Italy

7. Regional Health Authority of Emilia-Romagna, Italy

8. Regional Health Authority of Lombardy, Italy

9. Regional Health Authority of Friuli-Venezia Giulia, Italy

Citation style for this article:

Rizzo C, Salcuni P, Nicoletti L, Ciufolini MG, Russo F, Masala R, Frongia O, Finarelli AC, Gramegna M, Gallo L, Pompa MG, Rezza G, Salmaso S, Declich S.

Epidemiological surveillance of West Nile neuroinvasive diseases in Italy, 2008 to 2011. Euro Surveill. 2012;17(20):pii=20172. Available online: http://www.

eurosurveillance.org/ViewArticle.aspx?Articleld $=20172$

Article submitted on 12 January 2012 / published on 17 May 2012

We describe the geographical and temporal distribution of West Nile neuroinvasive diseases (WNND) cases in Italy from 2008 to 2011. The increasing number of confirmed human cases from eight in 2008 to 18 in 2009 and the occurrence of the virus in a larger geographical area in 2009 (moving from east to west) prompted the Ministry of Health to publish, in spring 2010, a national programme for WNND human surveillance, comprising veterinary and vector surveillance. Subsequently, in 2011, a new national plan on integrated human surveillance of imported and autochthonous vector-borne diseases (chikungunya, dengue and West Nile disease) was issued. Between 2008 and 2011, 43 cases of WNND were reported from five regions in Italy with a case fatality rate of $16 \%$. The incidence of WNND during the entire study period was 0.55 per 100,000 population (range: $0.06-0.23$ per 100,000). During 2011, two new regions (Friuli-Venezia Giulia and Sardinia) reported confirmed cases in humans. Integrated human, entomological and animal surveillance for West Nile virus is a public health priority in Italy and will be maintained during 2012.

\section{Introduction}

West Nile Virus (WNV) infection was first identified in Italy in 1998, when the disease was detected in horses in Tuscany, with no rise in human neurological cases detected at the time [1]. After the WNV epidemic in horses in Tuscany in 2001, the Ministry of Health decided to implement a national veterinary surveillance programme. The aim of the veterinary surveillance programme was to detect the introduction of WNV and it was in place in 15 Italian wetland areas, chosen due to the presence of a significant number of water fowl, including migratory bird species that can represent a possible risk of virus introduction [2]. The plan foresees
Italian regions to adopt the operative procedure for entomological, sentinel bird and horse surveillance in coordination with the West Nile Disease (WND) National Reference Laboratory of the Public Veterinarian Health Department (Istituto Zooprofilattico Sperimentale) in Teramo, and the National Reference Laboratory for Vector Surveillance of the National Institute of Health (Istituto Superiore di Sanità, ISS) [3].

In summer 2005, WNV activity was detected again in the north-eastern part of Italy in sentinel chicken [4] whereas in summer 2008, WNV was confirmed in horses with neurological symptoms in the regions Veneto and Emilia-Romagna. This evidence prompted the immediate implementation of a WNV surveillance plan for human surveillance of West Nile neuroinvasive disease (WNND) in the two affected regions in June 2008 [5-8]. During the remaining six months until November 2008, following the implementation of the plan, a total of eight human cases of WNND were reported in the two regions during $2008[6,7,9]$. In 2009, the number of human WNND cases increased to a total of 18 in that year and included new wet areas surrounding the Po river (nine cases in Emilia-Romagna, seven in Veneto and two in Lombardy) [5-7].

After the number of human cases had increased from eight in 2008 to 18 in 2009 and the geographical distribution WNND had widened in 2009 with the virus expanding from east to west, the Ministry of Health $(\mathrm{MoH})$ published, during spring 2010, a national plan for WNND human surveillance in Italy that integrated veterinary and vector surveillance [10]. Subsequently, in 2011, a new national plan on integrated human surveillance of imported and autochthonous vector-borne disease (chikungunya, dengue and West Nile disease) 
was issued [11]. In this report we describe the geographical and temporal distribution of WNND cases in Italy, from 2008 to 2011.

\section{Methods}

The national surveillance system

The national plan for human surveillance defined 'affected areas' as provinces (secondary administrative units) were laboratory-confirmed WNV infections in horses and/or humans had been notified in previous years or during the surveillance period (defined as between 15 June and 15 November, the period with the highest vector activity). Identification of an affected area immediately triggers the definition of the 'surveillance area' that represents the regional territory of the affected area were the competent vector is present.

During the surveillance period, activities to be carried out by local and regional health authorities are different for affected and surveillance areas. Affected areas identified within the national veterinary programme are published every week on the IZS website [12].

When an affected area is defined by the veterinary programme, local health authorities have to activate an active surveillance system for WNND in workers employed on the farms where equine cases of WNND have been identified and in individuals living or working in the surrounding area (province). Moreover, measures for vector control have to be implemented immediately. At the same time, passive surveillance has to be set up in the surveillance area, requesting physicians to report all possible, probable and confirmed WNND cases using a modified European case definition [13]:

Only probable and confirmed cases have to be reported to the national level ( $\mathrm{MoH}$ and ISS). A possible case is defined as any person meeting the clinical criteria of (fever $\geq 38,5^{\circ} \mathrm{C}$, and at least one of the following: viral encephalitis, viral meningitis, polyradiculoneuritis (a condition similar to Guillain-Barré syndrome), and acute flaccid paralysis. A case is considered probable if the patient meets the clinical criteria, and their serum sample shows either a WNV-specific antibody response ( $I g G$ or $\operatorname{IgM}$ ) with seroconversion from negative to positive or a four-fold increase in the seroconversion titre on two subsequent samples. A confirmed case is defined as any person meeting the clinical criteria and at least one of the following four laboratory criteria: (i) isolation of WNV from blood or cerebrospinal fluid (CSF), (ii) presence of IgM antibodies in the CSF detected by ELISA, (iii) detection of WNV RNA by RT-PCR in blood or CSF, or (iv) a specific antibody response (IgG or IgM) against WNV detected by neutralisation assay.

All possible cases have to be notified by the regional authorities to the $\mathrm{MoH}$ and to the ISS (National Centre for Epidemiology, Surveillance and Health Promotion) using a specific Internet-based software that is password-protected. The system permits the local or regional health authorities to introduce possible cases directly on the website and to update the entry when more information from diagnostic tests becomes available. The regional reference laboratory (or the hospital laboratory) has to confirm the case through isolation of WNV from blood or CSF, detection of IgM antibodies in CSF by ELISA, detection of WNV RNA by RT-PCR in blood or CSF, or by neutralisation test if a specific IgG or IgM antibody response was detected in the serum sample. In case a neutralisation test is not available at the local or regional level, patient sera should be sent to the National Reference Laboratory at ISS that will perform the neutralisation test for confirmation.

Moreover, if in the same year human cases of WNND are detected, immediate WNV nucleic acid amplification test (NAAT) screening of all blood and haematopoietic stem cells donations are introduced in affected areas (provinces), and in surveillance areas (regions) additional screening of solid organ donations, according to the blood directive $[14,15]$. At the national level, all blood, tissue and solid organ donors who travelled

TABLE 1

Distribution of cases of West Nile neuroinvasive disease by region and year, Italy, 2008-11 ( $\mathrm{n}=43)$

\begin{tabular}{|c|c|c|c|c|c|c|}
\hline Region & Provinces of exposure & 2008 & 2009 & 2010 & 2011 & Total $^{\mathrm{a}}$ \\
\hline Emilia-Romagna & Ferrara, Bologna, Modena & 3 & 9 & $0\left[+1^{b}\right]$ & 0 & 12 \\
\hline Veneto c & $\begin{array}{l}\text { Belluno, Padua, Rovigo, } \\
\text { Treviso, Venice, Vicenza }\end{array}$ & 5 & 7 & $3\left[+1^{b}\right]$ & 8 & $23^{c}$ \\
\hline Lombardy & Mantua & 0 & 2 & 0 & 0 & 2 \\
\hline Friuli-Venezia Giulia & Udine & 0 & 0 & 0 & 2 & 2 \\
\hline Sardinia & Oristano, Olbia & 0 & 0 & 0 & 4 & 4 \\
\hline Total $^{\mathrm{a}}$ & & 8 & 18 & 3 & 14 & 43 \\
\hline
\end{tabular}

a Not including imported cases.

Both cases imported from Romania.

These cases do not include West Nile fever cases identified within the regional surveillance system in the Veneto region that have been reported in [8]. 
to an affected area have to be temporarily deferred for 28 days starting with the day they left the affected area [14].

In our analysis we did not include imported WNND cases notified in the regions Veneto and EmiliaRomagna, cases detected in organ donors [16], and West Nile fever cases identified within the regional surveillance system for WNV fever in the Veneto region. Those cases have already been reported and described in [8].

\section{Data analysis}

Incidence rates were calculated using the National Bureau of Statistics estimates of the Italian population for 2010 (mid-year) [17]. Comparison of categorical variables was assessed using the chi-square test. The analysis was carried out using STATA (Version 11).

\section{Results}

From June 2008 to November 2011, 43 confirmed WNND cases were notified in Italy. The distribution of WNND cases by year and region is reported in Table 1. All cases described in the present report were confirmed cases.

All 43 cases reported not to have travelled abroad during the incubation period. However, two additional cases that occurred in 2010, one in the Emilia-Romagna and one in the Veneto region, reported to have travelled in Romania during the incubation period (within 15 days before the disease onset). Furthermore, a probable WNND case reported in 2011 in the Toscana region had IgM and IgG antibodies against Toscana virus (confirmed by neutralisation test), indicating acute disease, as well as IgG antibodies against WNV (confirmed by neutralisation test), suggesting a previous exposure to WNV. This patient was an immigrant from India and was therefore considered as an imported case. Notably, one case in 2009 and four cases in 2011 were reported in organ recipients who received organs from two donors resident in affected areas [15]. In our study data from the three imported cases and from the two donors and organ recipients are not included.

The median age of the 43 cases was 70 years (range: 33-88 years) during the entire study period, varying from 71.6 (range: $50-86$ years) in 2008 to 72.2 (range: 49-84 years) in 2009, 46.5 (range: 29-68 years) in 2010 and 68.8 (range: $33-88$ years) in 2011. The attack rate increased significantly with age $(p=0.0001)$ and the proportion of males was significantly higher than of females $(p=0.014)$. None of the patients were vaccinated against yellow fever, tick-borne encephalitis or Japanese encephalitis. For 30 of 43 cases follow-up information was available and 25 of 43 recovered.

The trend over time of human cases of neuroinvasive WNV infection by month of symptom onset and the geographical location of cases from 2008 to 2011 is shown in Figures 1 and 2. September was the peak
FIGURE 1

Cases of West Nile neuroinvasive disease by month of onset, Italy, 2008-11 $(n=43)$

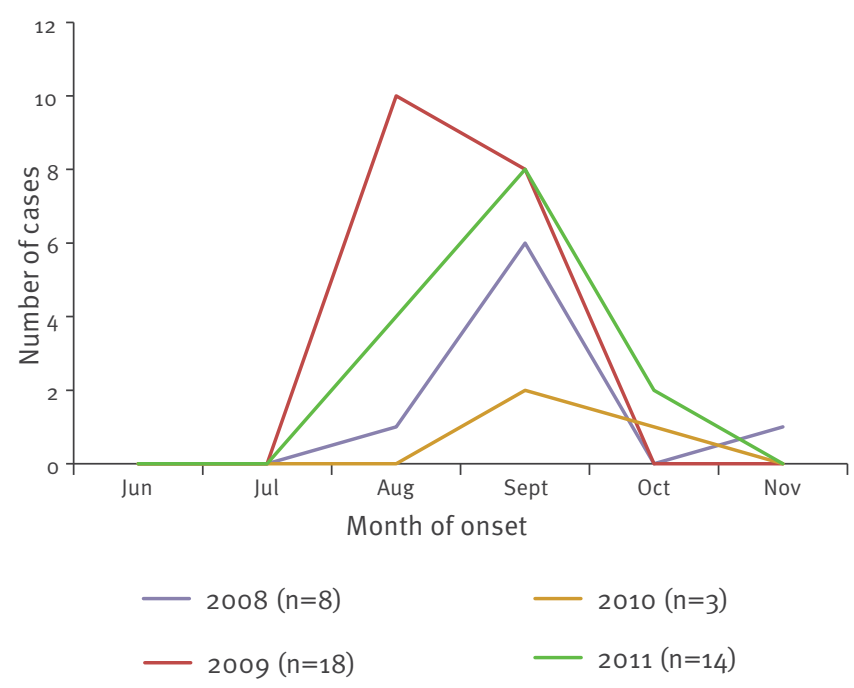

month in all years but 2009 when the peak was in August. The majority of WNND cases were reported from the provinces Ferrara, Treviso and Rovigo (Table 2). During 2011, two new regions (Friuli-Venezia Giulia and Sardinia) reported confirmed cases in horses, and later confirmed cases of WNND in humans.

All WNND cases were hospitalised. Seven of them (three in 2009 and four in 2011) died during hospitalisation, corresponding to a case fatality rate of seven of the 43 WNND cases (16\%). The median age of WNND cases who died was 76 years (range: $72-82$ years) in 2009, 70 years (range: 34-87 years) in 2011 and 73 years (range: $34-87$ years) overall. The reported fatalities do not consider the two donors resident in the affected areas.

\section{Discussion}

Overall from 2008 to 2011,43 confirmed autochthonous cases of WNND were reported in Italy. In this report we focus on WNND cases that conformed with the case definition of the Italian National Surveillance system. From 2008 to 2009, the incidence of West Nile disease increased two-fold and most of the affected areas were localised in north-eastern Italy, with the disease apparently moving from east to west. In 2010, the incidence rate decreased four-fold and cases were mostly localised in north-eastern Italy. It increased again three-fold in 2011, when cases occurred in the same provinces as in previous years and also in new regions. In fact, a new geographic pattern of WNV spread was observed in 2011, with a southward expansion that affected areas in the region Sardinia. During the entire study period, most of the areas affected by WNV were localised in north-eastern Italy, with the highest incidence rate $(2.43$ per 100,000$)$ observed in 
Provinces with confirmed human cases of West Nile neuroinvasive disease, Italy, 2008-11 (n=43)
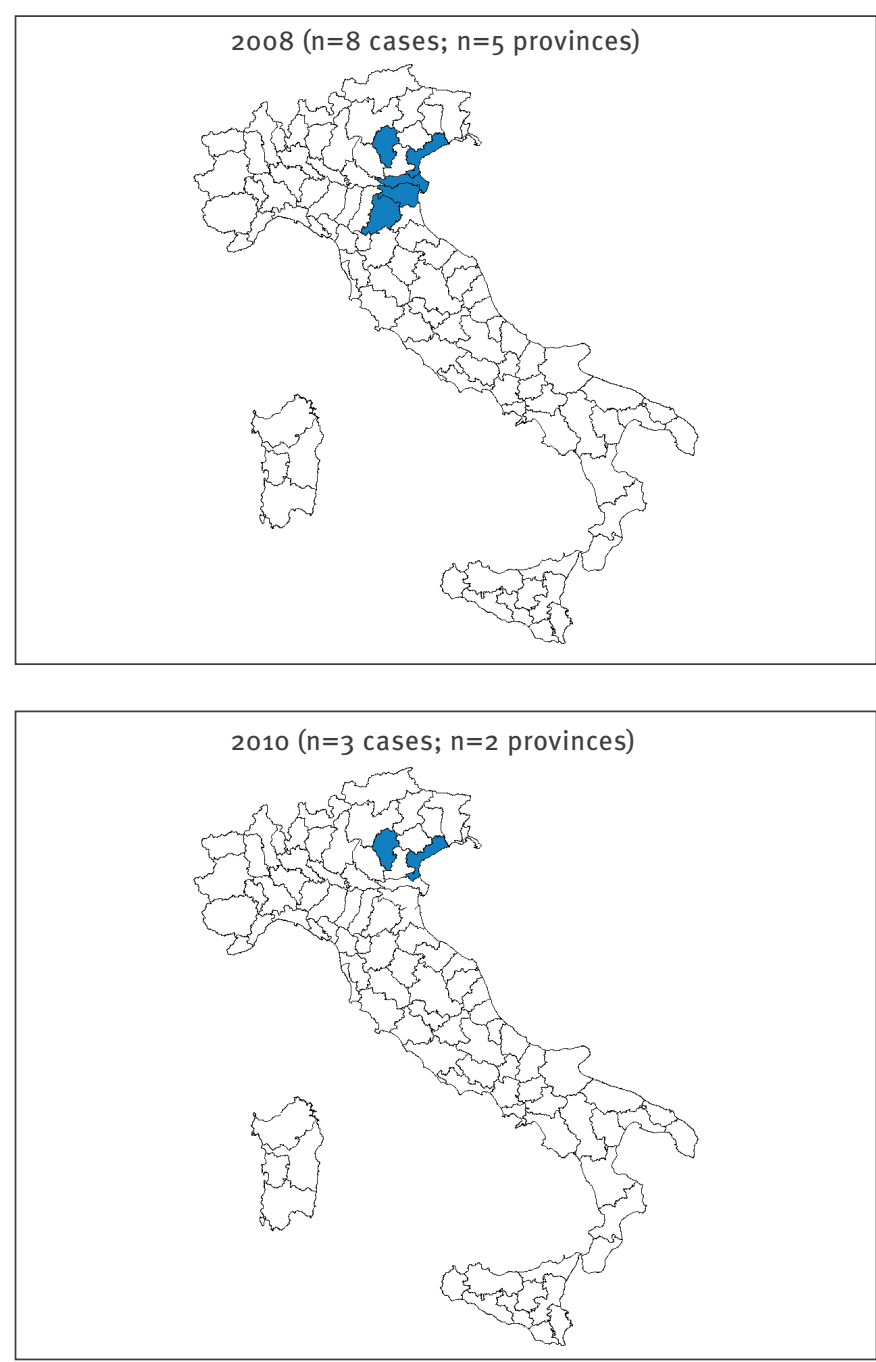

the Rovigo province in the Veneto region, a very humid and flat area limited by the rivers Po and Adige. In 2011, the highest incidence rate (1.80 per 100,000) was observed in a newly affected area, Oristano province in the Sardinia region.

We found a case fatality rate of $16 \%$ during the entire study period (2008-11) that was higher than in Israel (8.4\% in 2000 and $8 \%$ in the surveillance period $2005-$ 10), Romania (4.3\% in 1996) [18-20] and the United States (9\% in the surveillance period 1999-08) [21], and similar to that described Greece (17\% in 2010) [22]. In Italy, as described for Greece [22], an association between age and severe disease was observed.

During the study period, veterinary and human surveillance activities were intensified across the country $[2,23]$ in order to define a system able to detect WNV circulation as early as possible in infected animals for triggering immediate surveillance of WNND in humans. The calculation of incidence and case fatality rate of WNND cases in humans may be affected by underreporting
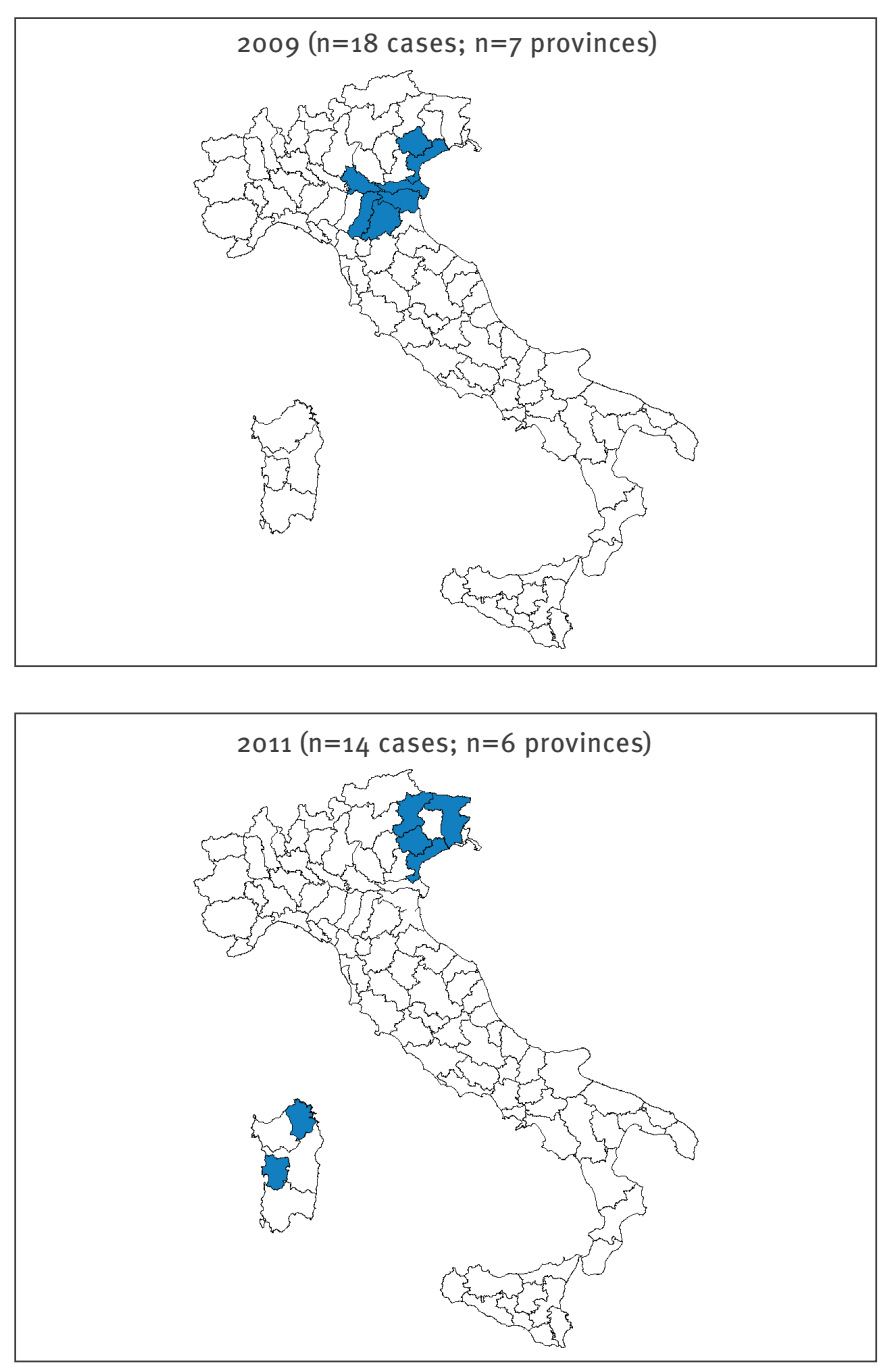

due to inappropriate use of the case definition at the regional level or due to under-reporting of cases who attend healthcare services but whose disease status is incorrectly diagnosed. However, since the case definition of human cases includes only WNND, it is unlikely that the clinical picture should be affected by underreporting and under-ascertainment (if also the case definition for West Nile fever was included in the National Surveillance System, a high degree of underreporting of clinical cases would be likely).

Notably, as far as we are aware, only WNV lineage 1 infections have been described in Italy since 2008, but the situation changed in 2011. Recently in 2011, co-circulation of both lineage 1 and 2 (the latter very closely related to the Hungarian lineage) has been demonstrated in north-east Italy [24], suggesting a probable introduction of lineage 2 in the southern European countries possibly along the routes of migratory birds $[24,25]$. However, as yet no human cases infected with WNV lineage 2 have been detected in the north-eastern affected areas of Italy. As a consequence, it can be 
TABLE 2

Characteristics of reported West Nile neuroinvasive disease, Italy, 2008-11 (n=43)

\begin{tabular}{|c|c|c|c|c|c|}
\hline \multirow{2}{*}{$\begin{array}{l}\text { Characteristics } \\
\text { Age group (years }\end{array}$} & \multicolumn{5}{|c|}{ Number of cases (incidence rate $/ 100,000$ ) } \\
\hline & 2008 & 2009 & 2010 & 2011 & Total \\
\hline$<30$ & $0(0)$ & $0(0)$ & $\mathrm{o}(0)$ & $\mathrm{o}(0)$ & o (o) \\
\hline $30-49$ & $0(0)$ & $1(0.04)$ & $2(0.09)$ & $3(0.13)$ & $6(0.27)$ \\
\hline $50-59$ & $2(0.21)$ & $0(0)$ & $\mathrm{o}(\mathrm{o})$ & $\mathrm{o}(\mathrm{o})$ & $2(0.21)$ \\
\hline $60-69$ & $1(0.12)$ & $4(0.46)$ & $1(0.12)$ & $2(0.23)$ & $8(0.93)$ \\
\hline$\geq 70$ & $5(0.44)$ & $13(1.15)$ & $0(0)$ & $9(0.79)$ & $27(2.38)$ \\
\hline \multicolumn{6}{|l|}{ Sex } \\
\hline Female & $3(0.08)$ & $5(0.13)$ & $1(0.03)$ & $5(0.13)$ & $14(0.35)$ \\
\hline Male & $5(0.13)$ & $13(0.34)$ & $2(0.05)$ & $9(0.24)$ & $29(0.77)$ \\
\hline \multicolumn{6}{|l|}{ Province (region) of residence } \\
\hline Ferrara (Emilia-Romagna) & $2(0.56)$ & $5(1.39)$ & $\mathrm{o}(0)$ & $\mathrm{o}(0)$ & $7(1.95)$ \\
\hline Bologna (Emilia-Romagna) & $1(0.10)$ & $2(0.20)$ & o (o) & o (o) & $3(0.30)$ \\
\hline Modena (Emilia-Romagna) & $0(0)$ & $2(0.29)$ & o (o) & $\mathrm{o}(\mathrm{o})$ & $2(0.29)$ \\
\hline Belluno (Veneto) & $0(0)$ & $\mathrm{o}(\mathrm{o})$ & $\mathrm{o}(\mathrm{o})$ & $1(0.47)$ & $1(0.47)$ \\
\hline Venice (Veneto) & $1(0.12)$ & $1(0.12)$ & $2(0.23)$ & $1(0.12)$ & $5(0.58)$ \\
\hline Vicenza (Veneto) & $3(0.35)$ & $0(0)$ & $1(0.12)$ & o (o) & $4(0.46)$ \\
\hline Treviso (Veneto) & $0(0)$ & $1(0.11)$ & $\mathrm{o}(\mathrm{o})$ & $6(0.68)$ & $7(0.79)$ \\
\hline Rovigo (Veneto) & $1(0.40)$ & $5(2.02)$ & o (o) & o (o) & $6(2.43)$ \\
\hline Olbia (Sardinia) & $0(0)$ & $0(0)$ & o (o) & $1(0.64)$ & $1(0.64)$ \\
\hline Oristano (Sardinia) & $0(0)$ & o (o) & o (o) & $3(1.80)$ & $3(1.80)$ \\
\hline Udine (Friuli-Venezia Giulia) & $0(0)$ & $\mathrm{o}(0)$ & o (o) & $2(0.37)$ & $2(0.37)$ \\
\hline Mantua (Lombardy) & $0(0)$ & $2(0.48)$ & o (o) & $\mathrm{o}(\mathrm{o})$ & $2(0.48)$ \\
\hline Total & $8(0.10)$ & $18(0.23)$ & $3(0.06)$ & $14(0.18)$ & $43(0.55)$ \\
\hline
\end{tabular}

Incidence rates were calculated using the 2010 mid-year population of the affected areas (provinces) and respective groups as denominator, available from the National Bureau of Statistics (www.istat.it).

expected that both lineages will be co-circulating in these areas in the next season probably. However it is impossible to predict if this will enhance or reduce the virulence of the virus in humans, should genetic recombination occur [26]. Moreover, genomic sequencing of the virus isolate from one of the four cases confirmed in Sardinia (Olbia province) showed that the virus belonged to WNV lineage 2 (unpublished data), similar to that circulating in Greece in 2010 (Dr Loredana Nicoletti, personal communication, Jan 2012). Another lineage 2 virus was isolated from a case of West Nile fever that was described in the Marche region (Ancona province) [27]. The case was a man in his late 50 os presenting with high fever and without evidence of neuroinvasive disease. For this reason he was not included in the present analysis. The genomic sequencing of that isolate showed that the virus belonged to WNV lineage 2 and had $99 \%$ identity to the complete genome of isolate goshawk-Hungary/04 and to the more recent Nea Santa-Greece-2010 isolate [28].

The confirmed cases from the Sardinia and Marche regions who were infected with WNV lineage 2, where diagnosed by detection of WNV RNA both in serum or plasma and in urine [27]. As previously reported, urine samples are more appropriate for WNV diagnosis because of longer shedding and higher viral load in the kidneys [29], which was also shown in experimental animal studies [30]. In fact, serum or plasma may give false-negative results due to the short duration of viraemia, while WNV can be shed in urine even years after the initial infection [29]. However, the use of the WNV RNA in urine is still debated [31].

In 2011, many autochthonous WNV human cases were reported in Europe and in neighbouring countries: 96 confirmed human cases in the European Union (69 in Greece, three in Hungary, 14 in Italy and 10 in Romania), and 207 in neighbouring countries (two in Albania, four in the Former Yugoslav Republic of Macedonia, 34 in Israel, 153 in the Russian Federation, three in Tunisia, three in Turkey and eight in Ukraine) [32].

In 2012, integrated human, entomological and animal surveillance will be continued in Italy in order to monitor the spread of WNV and to implement control measures for blood transfusions and organ donations, in accordance with the Blood Directive [33], to control and prevent transmission of the disease in humans. Comprehensive epidemiological, virological and entomological investigations are crucial for a better understanding of factors triggering the spread of WNV. In 
Italy, public health authorities (both veterinarian and human) should improve their collaboration at national, regional and local levels.

Establishing and having in place such an integrated surveillance could also be valuable to rapidly identify the risk of introduction of new vector-borne diseases with zoonotic potential, the most obvious candidates being chikungunya [34] and dengue fever [35], not to forget Malaria [36].
References

1. Autorino GL, Battisti A, Deubel V, Ferrari G, Forletta R, Giovannini A, et al. West Nile virus epidemic in horses, Tuscany region, Italy. Emerg Infect Dis. 2002;8(12):1372-8.

2. Calistri $P$, Giovannini A, Hubalek Z, Ionescu A, Monaco F, Savini G, et al. Epidemiology of West Nile in Europe and in the Mediterranean basin. Open Virol J. 2010;4:29-37.

3. Ministero della Salute. Approvazione del piano di sorveglianza nazionale per la encefalomielite di tipo West Nile [Approval of the national surveillance plan for West Nile encephalomyelitis]. Rome: Ministry of Health, 12 Feb 2008. G.U. Serie Generale n. 36. Italian. Available from: http://www.normativasanitaria.it/ jsp/dettaglio.jsp?aggiornamenti $=$ \&attoCompleto $=$ si $\& i d=25243$ \&page $=\&$ anno $=$ null

4. Rizzoli A, Rosa R, Rosso F, Buckley A, Gould E. West Nile virus circulation detected in northern Italy in sentinel chickens. Vector Borne Zoonotic Dis. 2007;7(3):411-7.

5. Angelini P, Tamba M, Finarelli AC, Bellini R, Albieri A, Bonilauri $P$, et al. West Nile virus circulation in Emilia-Romagna, Italy: the integrated surveillance system 2009. Euro Surveill. 2010 Apr 22;15(16):pii=19547. Available from: http://www. eurosurveillance.org/ViewArticle.aspx?Articleld=19547

6. Barzon L, Squarzon L, Cattai M, Franchin E, Pagni S, Cusinato $R$, et al. West Nile virus infection in Veneto region, Italy, 2008-2009. Euro Surveill. 2009 Aug 6;14(31):pii=19289. Available from: http://www.eurosurveillance.org/ViewArticle. aspx?Articleld $=19289$

7. Rizzo C, Vescio F, Declich S, Finarelli AC, Macini $P$, Mattivi A, et al. West Nile virus transmission with human cases in Italy, August - September 2009. Euro Surveill. 2009;14(40):pii=19353. Available from: http://www. eurosurveillance.org/ViewArticle.aspx?Articleld=19353

8. Barzon L, Pacenti M, Cusinato R, Cattai M, Franchin E, Pagni S, et al. Human cases of West Nile Virus Infection in north-eastern Italy, 15 June to 15 November 2010. Euro Surveill. 2011;16(33):pii=19949. Available from: http://www. eurosurveillance.org/ViewArticle.aspx?Articleld=19949

9. Rossini G, Cavrini F, Pierro A, Macini P, Finarelli A, Po C, et al. First human case of West Nile virus neuroinvasive infection in Italy, September 2. Euro Surveill. 2008 Oct 9;13(41):pii=19002. Available from: http://www.eurosurveillance.org/ViewArticle. aspx?Articleld $=19002$

10. Ministero della Salute. Sorveglianza della malattia di West Nile in Italia, 2010. [West Nile disease surveillance in Italy, 2010]. Rome: Ministry of Health; 21 Jul 2010. Italian. Available from: http://www.normativasanitaria.it/normsan-pdf/000o/34923_1. pdf

11. Ministero della Salute. Sorveglianza dei casi umani delle malattie trasmesse da vettori con particolare riferimento alla chikungunya, dengue e West Nile disease - 2011. [Surveillance of human cases of vector-borne diseases with a particular focus on chikungunya, dengue and West Nile disease - 2011]. Rome: Ministry of Health; 15 Jun 2011. Italian. Available from: http://www.normativasanitaria.it/normsan-pdf/0000/39170_1. pdf

12. Istituto G Caporale T. West Nile Disease in Italia nel 2011 [West Nile Disease in Italy in 2011]. Teramo: Istituto G. Caporale; 14 May 2012. Italian. Available from: http://sorveglianza.izs.it/ emergenze/west_nile/pdf/Bollettino_riassuntivo_WND2011. pdf

13. European Commission. Commission Decision of 28 April 2008 amending Decision 2002/253/EC laying down case definitions for reporting communicable diseases to the Community network under Decision No 2119/98/EC of the European Parliament and of the Council. (reference number C(2008) 1589) $2008 / 427 / E C$. Official Journal of the European Union 18.6.2008 L 159/65. Available from: http://eur-lex.europa.eu/ LexUriServ/LexUriServ.do?uri=0J:L:2008:159:0046:0090:EN: PDF

14. Centro Nazionale Sangue. Ulteriori indicazioni per la sorveglianza e la prevenzione della trasmissione trasfusionale dell'infezione da West Nile Virus (WNV) nella stagione estivoautunnale 2011. [Additional guidelines for the surveillance and prevention of transmission of West Nile virus (WNV) by blood transfusion in the summer-autumn season 2011]. Rome: National Blood Center; 14 July 2011. Italian. Available from: http://www.centronazionalesangue.it/sites/default/files/ prot.n. 1172.cns_.2011_ulteriori_indicazioni_wnv.pdf

15. Costa AN, Capobianchi MR, Ippolito G, Palu G, Barzon L, Piccolo G et al. West Nile virus: the Italian national transplant network reaction to an alert in the north-eastern region, Italy 2011. Euro Surveill. 2011;16(41):pii=19991. Available from: http://www.eurosurveillance.org/ViewArticle. aspx?Articleld=19991

16. Capobianchi MR, Sambri V, Castilletti C, Pierro AM, Rossini $G$, Gaibani P, et al. Retrospective screening of solid organ 
donors in Italy, 2009, reveals unpredicted circulation of West Nile virus. Euro Surveill. 2010;15(34): $\mathrm{pii}=19648$. Available from: http://www.eurosurveillance.org/ViewArticle. aspx?Articleld $=19648$

17. Istituto Nazionale di Statistica (Istat). Popolazione Residente al 1 Gennaio 2010 per età, sesso e stato civile. [Resident population on 1 Jan 2010 by age, sex and marital status]. Rome: Istat. Italian. Available from: http://demo.istat.it/ pop2010/index.html

18. Weinberger M, Pitlik SD, Gandacu D, Lang R, Nassar F, Ben DD, et al. West Nile fever outbreak, Israel, 2000: epidemiologic aspects. Emerg Infect Dis. 2001;7(4):686-91.

19. Tsai TF, Popovici F, Cernescu C, Campbell GL, Nedelcu NI. West Nile encephalitis epidemic in southeastern Romania. Lancet. 1998;352(9130):767-71.

20. Kopel E, Amitai Z, Bin H, Shulman LM, Mendelson E, Sheffer R. Surveillance of West Nile virus disease, Tel Aviv district, Israel, 2005 to 2010. Euro Surveill. 2011;16(25): pii=19894. Available from: http://www.eurosurveillance.org/ViewArticle. aspx?Articleld $=19894$

21. Lindsey NP, Staples JE, Lehman JA, Fischer M; Centers for Disease Control and Prevention (CDC). Surveillance for human West Nile virus disease - United States, 1999-2008. MMWR Surveill Summ. 2010;59(2):1-17.

22. Danis K, Papa A, Theocharopoulos G, Dougas G, Athanasiou M, Detsis $M$, et al. Outbreak of West Nile virus infection in Greece, 2010. Emerg Infect Dis. 2011;17(10):1868-72.

23. Salcuni P, Rizzo C. [West Nile disease: review of clinical features and risk factors associated with severe disease]. Infez Med. 2011;19(1):5-15. Italian.

24. Savini G, Capelli G, Monaco F, Polci A, Russo F, Di Gennaro $A$, et al. Evidence of West Nile virus lineage 2 circulation in Northern Italy. Vet Microbiol. 2012. [Epub ahead of print].

25. Barboza F, loos S, Ait-El-Belghiti F, Gauthier V, La Ruche G, Capek I, et al. West Nile Outbreak in the Mediterranean Region, August-November 2010. International Meeting on Emerging Disease and Surveillance (IMED) 2011; 4-7 Feb 2011; Vienna, Austria.

26. Pickett BE, Lefkowitz EJ. Recombination in West Nile Virus: minimal contribution to genomic diversity. Virol J. 2009;6:165.

27. Bagnarelli P, Marinelli K, Trotta D, Monachetti A, Tavio $M$, Del GR, et al. Human case of autochthonous West Nile virus lineage 2 infection in Italy, September 2011. Euro Surveill. 2011;16(43): pii=20002. Available from: http://www. eurosurveillance.org/ViewArticle.aspx?Articleld=20002

28. Krisztalovics K, Ferenczi E, Molnar Z, Csohan A, Ban E, Zoldi V, et al. West Nile virus infections in Hungary, AugustSeptember 2008. Euro Surveill. 2008 Nov 6;13(45):pii=19030. Available from: http://www.eurosurveillance.org/ViewArticle. aspx?Articleld $=19030$

29. Murray K, Walker C, Herrington E, Lewis JA, McCormick J, Beasley DW, et al. Persistent infection with West Nile virus years after initial infection. J Infect Dis. 2010;201(1):2-4.

30. Tonry JH, Xiao SY, Siirin M, Chen H, Da Rosa AP, Tesh RB. Persistent shedding of West Nile virus in urine of experimentally infected hamsters. Am J Trop Med Hyg. 2005;72(3):320-4.

31. Gibney KB, Lanciotti RS, Sejvar JJ, Nugent CT, Linnen JM, Delorey MJ, et al. West nile virus RNA not detected in urine of 40 people tested 6 years after acute West Nile virus disease. Infect Dis. 2011;203(3):344-7.

32. European Centre for Disease Prevention and Control (ECDC). Reported cases of West Nile fever map, for the EU and neighbouring countries. Stockholm: ECDC. [Accessed: 13 Jan 2012]. Available from: http://ecdc.europa.eu/en/activities/ diseaseprogrammes/emerging_and_vector_borne_diseases/ Pages/West_Niles_fever_Risk_Maps.aspx.

33. European Commission. Directive 2002/98/EC of the European Parliament and of the Council of 27 January 2003 setting standards of quality and safety for the collection, testing, processing, storage and distribution of human blood and blood components and amending Directive 2001/83/EC. Official Journal of the European Union. L 33/30. Luxembourg: Publications Office of the European Union; 2003. Available from: http://eur-lex.europa.eu/LexUriServ/LexUriServ.do?uri= OJ:L:2003:033:0030:0040:EN:PDF

34. Rezza G. Chikungunya and West Nile virus outbreaks: what is happening in north-eastern Italy? Eur J Public Health. 2009;19(3):236-7.

35. Gould EA, Gallian P, De Lamballerie X, Charrel RN. First cases of autochthonous dengue fever and chikungunya fever in France: from bad dream to reality! Clin Microbiol Infect. 2010;16(12):1702-4.

36. Danis K, Baka A, Lenglet A, Van BW, Terzaki I, Tseroni M, et al. Autochthonous Plasmodium vivax malaria in Greece, 2011.
Euro Surveill. 2011;16(42):pii=19993. Available from: http:// www.eurosurveillance.org/ViewArticle.aspx?Articleld=19993 